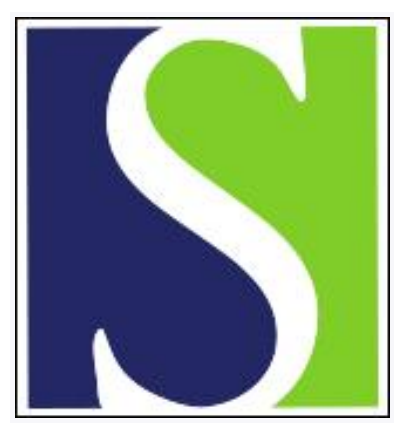

Scand J Work Environ Health 1984;10(6):403-408

https://doi.org/10.5271/sjweh.2303

Issue date: Dec 1984

Physical load on the cardiovascular system in different work tasks.

by Ilmarinen J

The following articles refer to this text: 2016;42(4):291-298;

2019;45(1):90-97

This article in PubMed: www.ncbi.nlm.nih.gov/pubmed/6535243

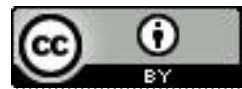




\title{
Physical load on the cardiovascular system in different work tasks
}

\author{
by Juhani llmarinen, $\mathrm{PhD}^{1}$
}

\begin{abstract}
ILMARINEN J. Physical load on the cardiovascular system in different work tasks. Scand $J$ Work Environ Health 10 (1984) 403-408. This review of the cardiovascular load at work is based on the concept of stress and strain in dynamic work. The relationship between oxygen consumption $\left(\mathrm{VO}_{2}\right)$ and heart rate (HR) and work load and the effects of intervening variables are described. The relationship between relative aerobic strain (RAS) and HR is shown to be dependent on the type and combination of muscular work. Significant differences in cumulative HR curves over 8 -h shifts have been detected between the profile groups "producing muscle forces" or "coordinating motor functions" and others; the HR remained above the level of 110 beats $\cdot \min ^{-1}$ for about 50,30 , and $5 \%$ of the shift time, respectively. $\mathrm{VO}_{2}, \mathrm{HR}$, and $\mathrm{RAS}$ are described in more detail during tasks in milk delivery, mail delivery, and logging, during tasks in the construction and steel industries, and during tasks in the municipal sector. Special attention is paid to work tasks in which the load on the cardiovascular system is above the "acceptable" level. Peak loads which increase strain to the maximal RAS level are described. The change in RAS with ageing is shown to increase in work tasks which include the production of muscle forces and the coordination of motor functions.
\end{abstract}

Key terms: age, heart rate, oxygen consumption, peak load, profile group, relative aerobic strain.

In most industrialized countries today, it seems to be common belief that workplaces are highly mechanized and that hard muscular work is no longer necessary. Experience in work physiology does not concur with these assumptions however. On the basis of field studies carried out in several thousand workplaces over the last 30 years, Rutenfranz and co-workers (13) have recently commented on this opinion and described the situation in a more realistic way. Experience in Finland from intensive field studies involving several hundred workplaces in the last 10 years also indicates that muscular work has not disappeared but that the physical load has changed and become more onesided and more static than before.

Rutenfranz et al (13) point out that people are perhaps overimpressed by the outstanding technical developments applied in some processes, and they therefore neglect the traditional work conditions still remaining.

\section{Stress-strain concept}

The use of the stress-strain concept is practical in the study of the effect of physical load on the cardiovascular system (12). The stress-strain concept is based on three physiological facts. Stress can be objectively described from the measurement of oxygen consumption $\left(\mathrm{V}_{2}\right)$ during work. Strain at a given $\dot{\mathrm{VO}}_{2}$

\footnotetext{
I Department of Physiology, Institute of Occupational
} Health, Helsinki, Finland.

Reprint requests to: Dr J Ilmarinen, Institute of Occupational Health, Laajaniityntie 1, SF-01620 Vantaa, Finland. varies subjectively depending on the individual's cardiopulmonary work capacity. A $\dot{\mathrm{VO}}_{2}$ of 0.9 $1 \cdot \min ^{-1}$ means a relative aerobic strain $\left(\dot{\mathrm{V}}_{2}\right.$ at work as percentage of the maximal $\dot{\mathrm{VO}}_{2}$ ) of $20 \%$ for an athlete, $45 \%$ for a 50 -year-old man, and $90 \%$ for an 8-year-old child. At this $\mathrm{VO}_{2}$ level the strain measured by heart rate for the aforementioned individuals varies from 90 to 190 beats $\cdot \min ^{-1}$. Thus the effects of physical load on the cardiovascular system are directly related to the individual's physical work capacity (12). The acceptable level of physical load varies from 30 to $50 \%$ of the maximal $\dot{\mathrm{VO}}_{2}$. It has been suggested that $30 \%$ of maximal $\mathrm{V}_{2}$ is acceptable for prolonged physical work without breaks. The $50 \%$ level should be the upper limit if work breaks are available (13).

\section{Stress and strain related to muscular work}

The relationship between the relative aerobic strain (RAS) and heart rate depends on the type and combination of muscular work (figure 1). Heart rate at a given RAS is the highest in industrial work that includes much static work (2). In milk delivery, which also includes driving, the average heart rate at $50 \%$ RAS is 122 beats $\cdot \mathrm{min}^{-1}(5)$. In municipal jobs, for which static muscular work is less dominant, the heart rate at the reference point is only 112 beats $\cdot \min ^{-1}$ (14). These findings indicate that the recommendations for critical thresholds of aerobic overstrain should be related to work content. Therefore a job analysis should always be one component of physiological field studies. 


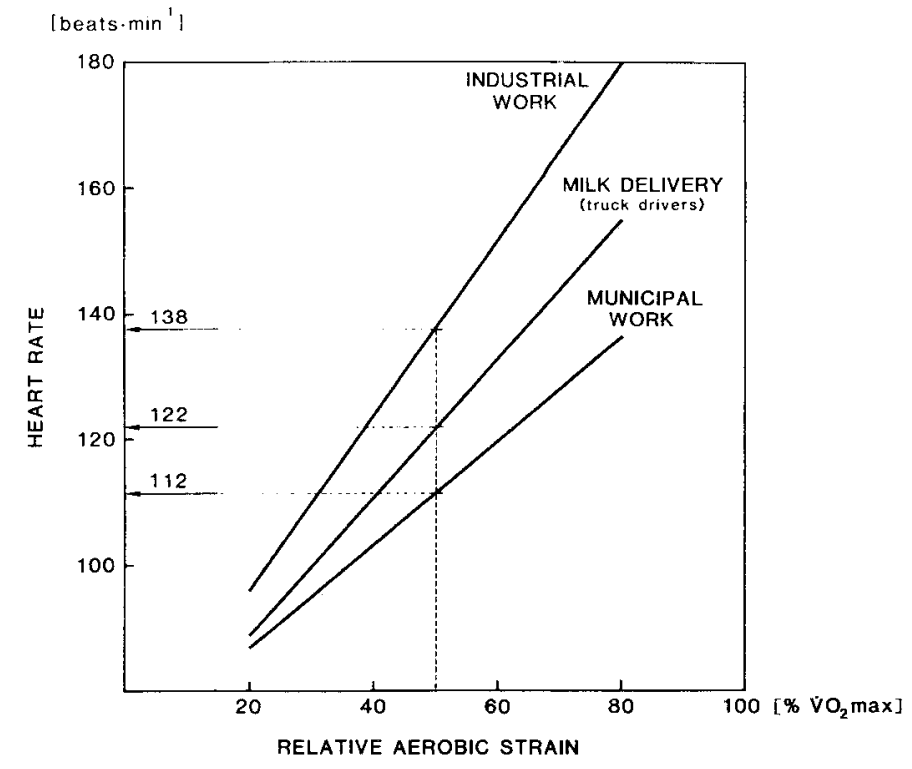

Figure 1. Relationship between relative aerobic strain and heart rate according to different muscular work in three types of work (2, $5,14)$. Industrial work includes the most and municipal work the least static work of large muscle groups $\left(\% \mathrm{VO}_{2} \max =\right.$ percentage of maximal oxygen consumption)

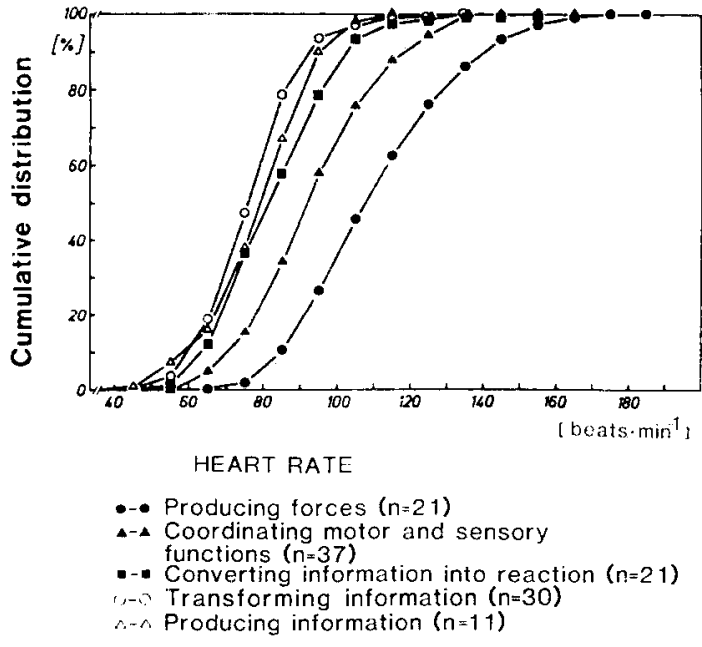

Figure 2. Cumulative distribution of heart rate in five groups according to job analysis [reprinted from IImarinen \& Rutenfranz (6)].

\section{Stress and strain related to work content}

In recent years studies have been carried out to demonstrate the work-related aspects of strain. Recordings of 8-h heart rate among different work groups according to job analysis (11) have shown very clearly the extent to which the strain at work varies (6). The cumulative distribution of heart rate in the group "producing forces" shows that more than $50 \%$ of the workshift in this group is worked above the level of 110 beats $\cdot \min ^{-1}$ (figure 2). For the group "coordinating motor and sensory functions," this reference point was 90 beats $\cdot \min ^{-1}$, and for the other groups it was about 70 beats $\cdot \min ^{-1}$. The results also show that information work led to a heart rate level above 90 beats $\cdot \min ^{-1}$ only $10 \%$ of the shift time, whereas in muscular work $10 \%$ of the shift time involved work above the level of 140 beats $\mathrm{min}^{-1}$. In information work the heart rate is at the rest level at least $20 \%$ of the shift time. Thus, even today, there are still great differences in cardiovascular strain related to work content.

In a study of 88 municipal jobs in Finland (14), the heart rate values demonstrated the variation of strain among employees 40 to 58 years of age (figure 3). The average work-related strain ranged from 70 to 100 beats $\cdot \min ^{-1}$ for the different profile groups. The strain was the highest during auxiliary work done by women (street sweeper, cleaner, kitchen helper) and during installation work done by men (machine mechanic, pipe filter, electrician). About a third of the heart rate range (HR rest - HR maximal) was activated in the groups.

The mean $\mathrm{VO}_{2}$ in the delivery of milk products (5) and mail delivery (4) is about $1.51 \cdot \mathrm{min}^{-1}$. In motor-manual logging the mean $\dot{\mathrm{VO}}_{2}$ is higher, about $1.91 \cdot \mathrm{min}^{-1}(10)$. Due to the great differences in the maximal $\mathrm{VO}_{2}$, the mean RAS in these three typical physical jobs is about $50 \%$ of the maximal $\mathrm{VO}_{2}$. The figures indicate that, for these jobs, the average aerobic strain at work is close to the upper internationally accepted limit for prolonged physical work even though the groups were adapted to heavy work.

\section{Task-related stress and strain}

A task-related analysis of stress and strain is the most adequate level for the detection of occupational physical stress factors which lead to overstrain and which should be avoided or changed. In milk delivery the loading of the truck at the dairy was heavier than unloading the truck and delivering milk products to 


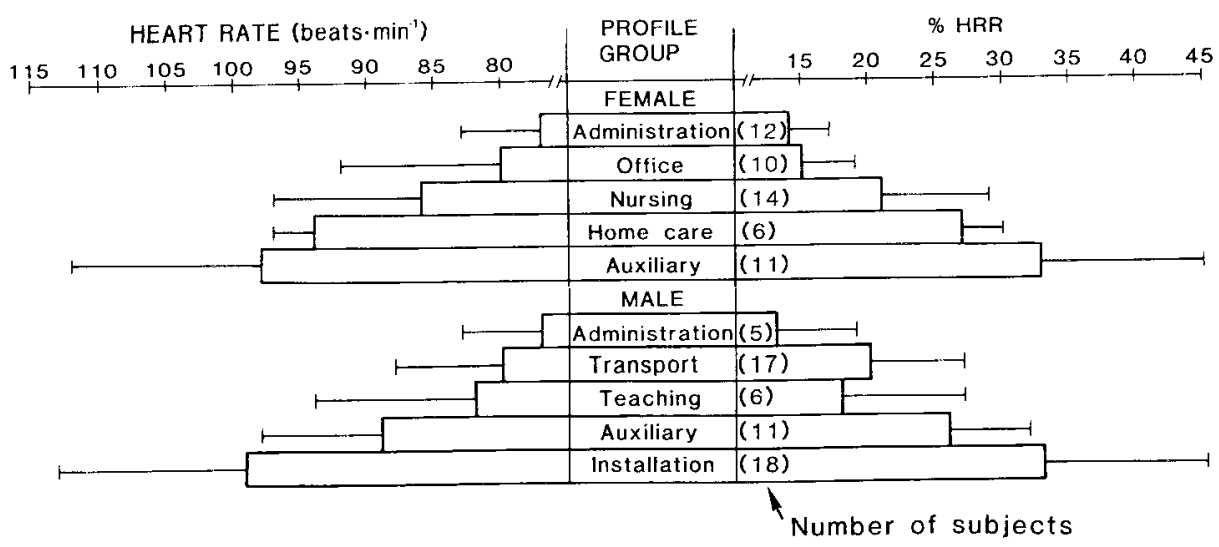

Figure 3. Means and standard deviations of the heart rate and the means and standard deviations of the heart rate range (\% HRR) in different profile groups of female and male municipal employees aged 45-58 years (14). [\% HRR = (HR work HR rest : HR max - HR rest) $\times$ 100]

shops (figure 4). During unloading the RAS depends on the work method. Carrying the milk cases, $20 \mathrm{~kg}$ each, is heavier than pushing the dollies, about 200 $\mathrm{kg}$ (5). In mail delivery the RAS depends on the work method, too, but then the RAS is even more related to the work pace (figure 5). In free-pace delivery, which is the usual delivery pace in Finland, the RAS is systematically higher than in the standard pace recommended by the Post and Telecommunications inspectors. Mail delivery by bicycle is more stressing than by foot with a mail bag or by foot with a mail cart. At free pace, bicycling exceeds the $50 \%$ RAS level, which is the same as the RAS involved in climbing stairs carrying a mail bag (4).

Motor manual logging also involves some differences between the typical work tasks. The bunching of wood is the heaviest task, with a $\dot{\mathrm{VO}}_{2}$ of 2.2 $1 \cdot \min ^{-1}$, both in winter and in autumn (10). Logging, which has been described as one of the heaviest jobs, today still includes heavy muscular work despite the use of a power saw.

A $21 \cdot \min ^{-1}$ level of $\mathrm{VO}_{2}$ at work is not exceptional in technically developed countries. Results from the Federal Republic of Germany $(8,9)$ indicate that a high level of stress is typical for several tasks in construction work and in the iron and steel industry. In construction work the $\dot{\mathrm{V}}_{2}$ exceeds 2.0 $1 \cdot \min ^{-1}$ during the tasks of pulling the steel rods from the stack, carrying them, and laying them out (9). During five other tasks the $\dot{\mathrm{V}} \mathrm{O}_{2}$ exceeds 1.5 $1 \cdot \min ^{-1}$ (loading a wheelbarrow with bricks, pushing and unloading the wheelbarrow, pouring and setting concrete mix, climbing to a crane $40 \mathrm{~m}$ high, lifting support beams for walls and ceilings). In the iron and steel industry the $\dot{\mathrm{V}}_{2}$ is somewhat lower than in construction work, but also this industry includes heavy tasks, eg, manually removing accumulated deposits from a furnace closing machine, transporting and laying bricks in the casting pit (extreme heat load), taking a sample to check the quality of the cast and rapidly adding heavy bags of chemical compo-

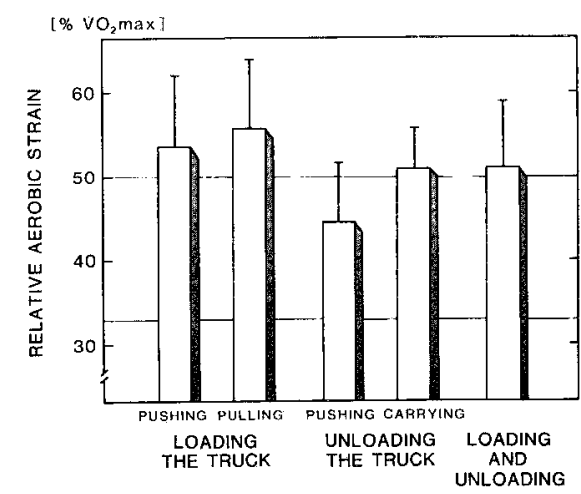

Figure 4. Means and standard deviations of the relative aerobic strain during different tasks in the delivery of milk products - Based on measurements of 10 truck drivers (5). ( $\% \mathrm{VO}_{2} \max =$ percentage of maximal oxygen consumption)

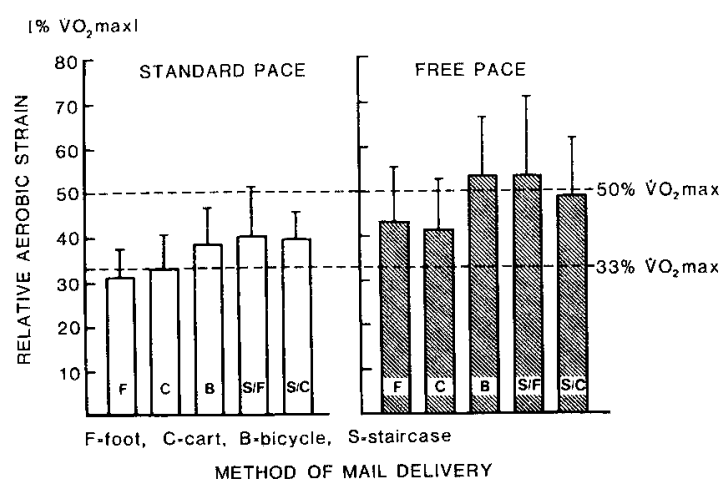

Figure 5. Means and standard deviations of the relative aerobic strain during mail delivery according to work pace and work method - Based on measurements of 11 postmen [reprinted from IImarinen et al (4)]. $\left(\% \mathrm{VO}_{2} \max =\right.$ percentage of maximal oxygen consumption)

nents to the cast, manually controlling a sheet-metal grinder and polisher. The individual RAS values increase up to $68 \%$ during grinding and up to $63 \%$ during brick transport (8). 


\section{Peak loads related to work tasks}

Although the mean strain in municipal work groups (see figure 3) was rather low, task-related strain showed that workers older than 45 years also have heavy tasks in the municipal sector (14).
The list of work tasks carried out at two heart rate levels exceeding the acceptable criteria of 40 beats $\cdot \min ^{-1}$ above the resting level at the workplace are presented in tables 1 and 2. The results demonstrate two aspects. First, the range of mean heart rate within one task is large. Thus the same task

Table 1. Mean duration of the work tasks and the range of mean heart rate (HR mean) for municipal jobs for which the HR mean was $110-119$ beats $\cdot \min ^{-1}(14)$

\begin{tabular}{lccc}
\hline Work task & $\begin{array}{c}\text { Number of } \\
\text { subjects (N) }\end{array}$ & $\begin{array}{c}\text { Mean duration } \\
\text { of task (min) }\end{array}$ & $\begin{array}{c}\text { Range of HR mean } \\
\text { (beats } \cdot \text { min-1) }\end{array}$ \\
\hline Sweeping, raking & 9 & 32 & $87-136$ \\
Assembling, repairing & 8 & 17 & 10 \\
Operating a machine & 6 & 49 & $13-122$ \\
Riding a bicycle & 1 & 64 & 30 \\
Carpentry & 4 & 30 & $109-129$ \\
Shoveling (gravel) & 10 & 33 & $100-132$ \\
Service and maintenance work & 18 & $99-147$ \\
\hline
\end{tabular}

Table 2. Mean duration of the work tasks and the range of the mean heart rate (HR mean) for municipal jobs for which the HR mean was $120-129$ beats $\cdot \min ^{-1}(14)$

\begin{tabular}{|c|c|c|c|}
\hline Work task & $\begin{array}{l}\text { Number of } \\
\text { subjects (N) }\end{array}$ & $\begin{array}{c}\text { Mean duration } \\
\text { of task (min) }\end{array}$ & $\begin{array}{l}\text { Range of HR mean } \\
\text { (beats } \cdot \min ^{-1} \text { ) }\end{array}$ \\
\hline $\begin{array}{l}\text { Lifting, carrying (load } 10-25 \mathrm{~kg} \text { ) } \\
\text { Carpentry, hands above shoulder level } \\
\text { Pushing, pulling a loaded cart } \\
\text { Striking, hewing with a hammer or crowbar }\end{array}$ & $\begin{array}{r}29 \\
1 \\
7 \\
5\end{array}$ & $\begin{array}{r}8 \\
36 \\
17 \\
11\end{array}$ & $\begin{array}{l}90-148 \\
126 \\
108-156 \\
100-158\end{array}$ \\
\hline
\end{tabular}

Table 3. Number of minutes in heart rate classes over 150 beats $\cdot \min ^{-1}$ during industrial work done by three different male subjects (6).

\begin{tabular}{|c|c|c|c|c|c|c|c|}
\hline \multirow{2}{*}{ Branch } & \multirow{2}{*}{$\begin{array}{l}\text { Age of } \\
\text { subject } \\
\text { (years) }\end{array}$} & \multirow{2}{*}{ Work task } & \multicolumn{5}{|c|}{ Heart rate class beats $\cdot \min ^{-1}$ ) } \\
\hline & & & $150-159$ & $160-169$ & $170-179$ & $180-189$ & $190-199$ \\
\hline Construction industry & 34 & $\begin{array}{l}\text { Striking and shoveling frozen } \\
\text { ground }\end{array}$ & 46 & 16 & 6 & 8 & 1 \\
\hline Iron and steel industry & 37 & $\begin{array}{l}\text { Removing deposits from a } \\
\text { furnace closing machine with } \\
\text { a press-hammer and iron rod }\end{array}$ & 19 & 11 & 7 & 11 & 1 \\
\hline Chemical industry & 30 & $\begin{array}{l}\text { Removing slag from the inside } \\
\text { walls of the furnace with an } \\
\text { iron rod }\end{array}$ & 103 & 50 & 13 & 6 & - \\
\hline
\end{tabular}

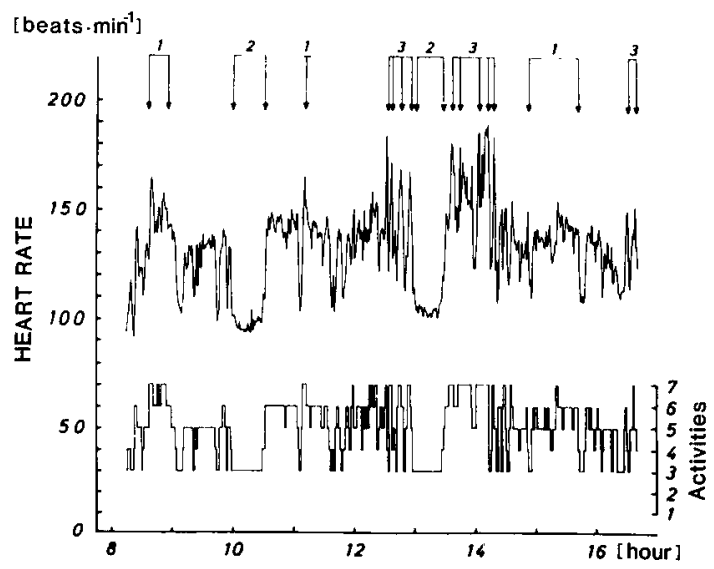

Flgure 6. Individual heart rate curve over the shift, demonstrating the cardiovascular response to striking the ground with a pick (code 3), shoveling soil (code 1), and recovering during rest pauses (code 2) (2).

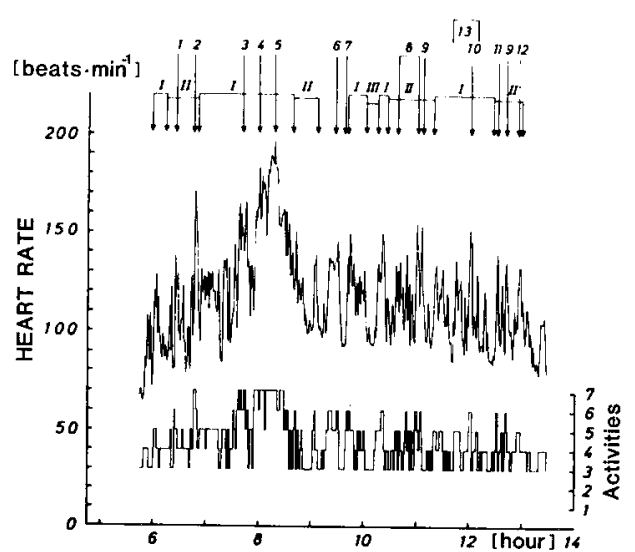

Figure 7. Individual heart rate curve of a smelter in a blast furnace (2). The heart rate during the manual removal of deposits with an iron rod (code 5) reached the maximal heart rate level. 
can be carried out at different intensities. During sweeping and raking one subject's mean heart rate was 87 beats $\cdot \min ^{-1}$ and another's was 136 beats $\cdot \min ^{-1}$ (table 1$)$. Mean heart rate varied remarkably also in maintenance and service tasks. Second, the results indicate the mean duration of the heavy tasks. At the heart rate level of 110-119 beats $\cdot \mathrm{min}^{-1}$ the mean duration was usually longer than $30 \mathrm{~min}$ (table 1). At the level of 120-129 beats $\cdot \min ^{-1}$ the range of the mean was still very large (table 2). Among 29 subjects who had been carrying loads of 10 to $25 \mathrm{~kg}$ an average of $8 \mathrm{~min}$, the individual mean heart rate varied from 90 to 148 beats $\cdot \min ^{-1}$. Pushing and pulling a loaded cart and striking blows with a hammer or iron rod can be extremely heavy tasks for older workers, as the mean heart rates of 156 and 158 beats $\cdot \mathrm{min}^{-1}$ demonstrate.

Task-related strain indicates large variation from one individual to another. This finding can be explained both by differences in individual work capacity and by the organizational aspects of work. The frequency, duration, and intensity of heavy tasks, rest pauses between the tasks, etc, have considerable effects on cardiovascular load during the workshift.

Determining the real time relationship between work tasks and strain depends on knowledge of the individual heart rate curves over the shift. The following two examples demonstrate the task-strain relationship in real time analysis (2). The first heart rate curve (figure 6) shows responses to striking the ground with a pick and shoveling soil. The work phases were long, and there were only two rest pauses. During the rest periods the mean heart rate did not reach the resting level (2). The second heart rate curve (figure 7) demonstrates the task-strain relationship for a smelter in a blast furnace. This work was done in temperatures of $42-46^{\circ} \mathrm{C}$ (globe temperature). Figure 7 shows that the smelter had more than 10 different tasks during the day, and no systematic rest pauses were available between the tasks. Continuous change from one task to another is typical for this job (2).

These examples indicate that, even today, the physical load at work can be so high that the maximal level of cardiovascular capacity is reached. Three cases are described in table 3 . The first man was striking and shoveling frozen ground (see also figure 6). The work was done on a contract basis. At a tempo of 20 strikes/min his heart rate reached the maximum level of 190 beats $\cdot \min ^{-1}$. It was above the level of 170 beats $\cdot \min ^{-1}$ for $15 \mathrm{~min}$. The second man worked with a press-hammer and an iron rod to remove deposits from a furnace closing machine. Heavy dynamic and static work was combined with poor climatic conditions. His heart rate was above 180 beats $\cdot \min ^{-1}$ for $12 \mathrm{~min}$ and reached a maximum of 192 beats $\cdot \min ^{-1}$ for $1 \mathrm{~min}$. The third man worked in a power plant. His job was to remove the slag from

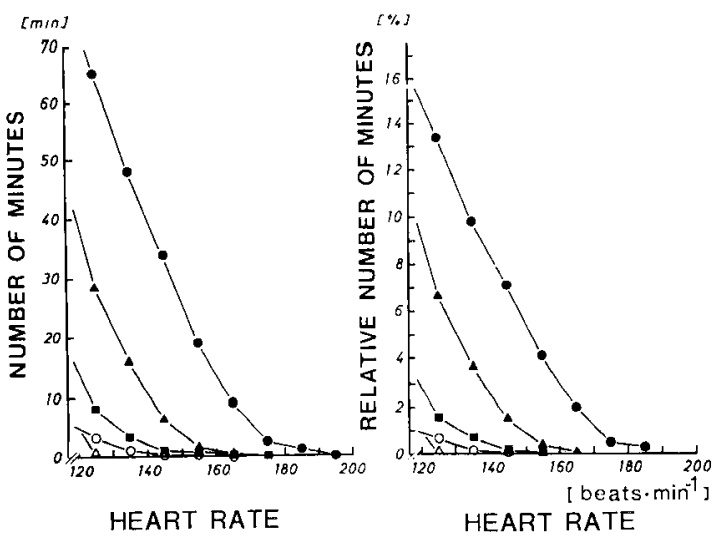

-- Producing forces $(n=21)$

- Coordinating motor and sensory functions $(n=37)$

- Converting information into reaction $(n=21)$

$0-0$ Transforming information $(n=30)$

$\Delta-\triangle$ Producing information $(n=11)$

Figure 8. Amount of peak loads related to work content [reprinted from IImarinen et al (3)].

the inside walls of the furnace. He used $12-\mathrm{kg}$ iron rods that were $4 \mathrm{~m}$ long. He worked for $19 \mathrm{~min}$ at a heart rate above 170 beats $\cdot \min ^{-1}$ and reached his maximum of 185 beats $\cdot \min ^{-1}$ for $1 \min (6)$.

From the examples the question can be posed of how typical such peak loads are at work. Figure 8 shows work-related peak loads. In the work group "producing forces," an average of about $10 \mathrm{~min}$ per day was worked above the heart rate level of 160 beats $\cdot \min ^{-1}$. Such high peak loads are not typical in sensorimotor work (coordinating sensory and motor functions, eg, crane driver), but a few minutes daily can be expected (3). These levels of peak loads can be harmless for young, healthy workers, but for older ones this may not be the case.

Strain which exceeds $50 \%$ of the maximal aerobic capacity is likely to include anaerobic load too. Short-term muscular effort combined with static muscle contractions can be worked out only with anaerobic energy metabolism. So far no relevant data on the anaerobic strain of professional work are available.

\section{Strain and age}

The capacity of the cardiovascular system decreases with age. At the age of 50 years, $15-20 \%$ of the capacity available at the age of 25 years has been lost. This fact has important consequences on the effects of physical load on the cardiovascular system among older workers. It has been suggested earlier that older workers are able to regulate their work intensity so that they are less stressed than younger workers (1). Experience shows that this is not always the case. In pace work workers may choose an RAS level which is higher than recommended, as the results for mail 


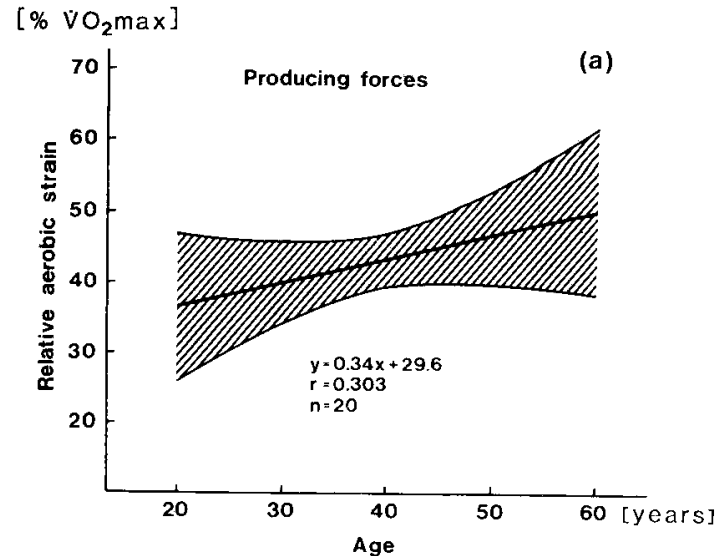

$\left[\% \dot{V}_{2} \max \right]$

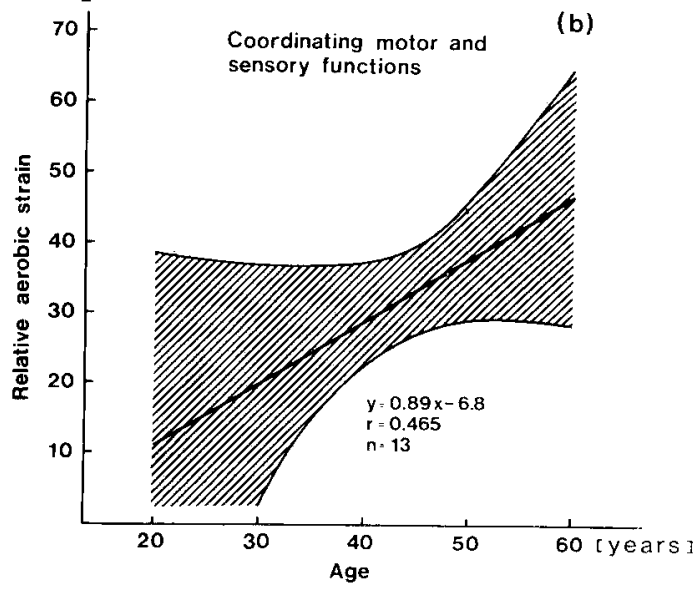

Figure 9. Relative aerobic strain related to age in hard muscular work (a) and in sensorimotor work (b) [reprinted from IImarinen \& Rutenfranz (7)]. ( $\% \mathrm{VO}_{2} \max =$ percentage of maximal oxygen consumption)

delivery indicate. The results for industrial groups also indicate that the RAS increases with age (figure 9). In hard muscular work (figure 9 a) the increasing tendency with age is clear, and the tendency is even much stronger in sensorimotor work (figure $9 \mathrm{~b}$ ). This result suggests that the more complicated the work tasks are, the higher the RAS can increase (7).

To summarize, physical load has definitely not disappeared from workplaces in most industrialized countries. The increasing tendency of static work places new demands on the cardiovascular system at work. Stress and strain is strongly related to work content, job, and work tasks. Physiological task analysis can reveal the critical characteristics of work. Individual task-strain curves in real time provide the information needed for improving work. Peak loads are still common at work, and their frequency, intensity, and durations should be checked so that also older workers are on the safe side of the stress border.

\section{References}

1. Ảstrand I. Degree of strain during building work as related to individual aerobic work capacity. Ergonomics 10 (1967) 293-303.

2. Ilmarinen J. Beziehungen zwischen beruflicher und sportlicher körperlicher Aktivität und kardiopulmonaler Leistungsfähigkeit. Untersuchungen bei Männern mittleren Alters unter besonderer Berücksichtigung prophylachtischer Aspekte der koronaren Durchblutungsstörungen. Deutsche Sporthochschule, Köln 1978. (Doctoral dissertation).

3. Ilmarinen J, Knauth P, Rutenfranz J, Karvonen MJ. Untersuchungen über unterschiedliche präventive $\mathrm{Ef}$ fekte von habituellen körperlichen Aktivitäten in Beruf bzw. Freizeit. I Prävalenz von Risikofaktoren für Herz- und Kreislaufkrankheiten in Gruppen mit unterschiedlicher habitueller körperlicher Aktivität. Int Arch Occup Environ Health 45 (1980) 15-33.

4. Ilmarinen J, Louhevaara V, Oja P. Oxygen consumption and heart rate in different modes of manual postal delivery. Ergonomics 27 (1984): 3, 331-339.

5. Ilmarinen $\mathbf{J}$, Nygård $\mathbf{C}-\mathrm{H}$. The effects of change in transport methods on stress and strain of truck driver's work. Ergonomics 25 (1982): 6, 518-519. (Abstract).

6. Ilmarinen J, Rutenfranz J. Assessment of physical activity at work and during leisure time. In: Stott FD, Raftery EB, Gouldning L, ed. ISAM 1979: Proceedings of the third international symposium on ambulatory monitoring. Academic Press, London, New York, Toronto, Sydney, San Francisco 1980, pp 285-297.

7. Ilmarinen J, Rutenfranz J. Occupationally induced stress, strain and peak loads as related to age. Scand $J$ Work Environ Health 6 (1980) 274-282.

8. Klimmer $F$, Kylian $H$, Ilmarinen $J$, Ilmarinen $R$, Meyer R, Piekarski C, Rutenfranz J. Belastung und Beanspruchung bei Tätigkeiten in der Eisen- und Stahlindustrie. Arbeitsmed Sozialmed Präventivmed 3 (1984) 49-54.

9. Klimmer F, Kylian H, Ilmarinen J, Rutenfranz J. Arbeitsmedizinische und arbeitsphysiologische Untersuchungen bei verschiedene Tätigkeiten in Bauhauptgewerbe. Arbeitsmed Sozialmed Präventivmed 6 (1983) $143-147$.

10. Kukkonen-Harjula K, Rauramaa R. Oxygen consumption of lumberjacks in logging with a power-saw. Ergonomics 27 (1984): 1, 59-65.

11. Rohmert W, Landau K. A new technique for job analysis. Taylor \& Francis Ltd, London and New York 1983.

12. Rutenfranz J. Arbeitsmedizinische Aspekte des Stressproblems. In: Nitsch JR, ed. Stress: Theorien, Untersuchungen, Massnahmen. Verlag Hans Huber, Benn-Stuttgart-Wien 1981, pp 379-390.

13. Rutenfranz J, Klimmer $F$, Ilmarinen J. Työelämän muutokset ja liikunnan harrastus [Changes in working life and physical activities]. Liikunta ja tiede 3 (1984) $100-110$.

14. Suurnäkki T, Nygård C-H, Peltomaa T, Järvenpää I, Järvinen $M$, Nieminen $K$, Huuhtanen $P$, Ilmarinen $J$. Työntekijäin kuormittuminen kunnallisissa ammateissa [Strain at work in municipal jobs]. In: Kunnallisten viranhaltijain ja työntekijäin eläkeikien perusteiden tutkimus [Grounds for the determination of retirement age in municipal occupations]. Työterveyslaitos, Helsinki 1984, pp $161-181$. 